\section{REVIEW ARTICLE}

\title{
Molecular mechanisms of lytic enzymes involved in the biocontrol activity of Trichoderma harzianum
}

\author{
S. Haran, H. Schickler and I. Chet
}

Author for correspondence: S. Haran. Tel : +972 89481315. Fax: + 97289468785.

Otto Warburg Center for Agricultural Biotechnology, The Hebrew University of Jerusalem, Faculty of Agriculture, Rehovot 76-100, Israel

Keywords: Tricboderma, lytic enzymes, mycoparasitism, biological control, heterologous genes

\section{Overview}

The many achievements of modern agriculture notwithstanding, certain cultural practices have actually enhanced the destructive potential of crop diseases caused by fungi. These practices include the use of genetically uniform crop plants in continuous monoculture, the use of plant cultivars susceptible to pathogens, and the use of nitrogenous fertilizers at concentrations that increase disease susceptibility. Plant-disease control has thus become heavily dependent on fungicides to combat the wide variety of fungal diseases that threaten agricultural crops (Waard et al., 1993). Studies aimed at replacing pesticides with environmentally safer methods are currently being conducted at many research centres. Biological control is a potent means of reducing the damage caused by plant pathogens and is environmentally nonhazardous. Although commercialized systems for the biological control of plant diseases are few, intensive activity is currently being geared towards the development of an increasing number of biocontrol agents.

Potential agents for biocontrol activity are rhizospherecompatible fungi and bacteria which exhibit antagonistic activity towards plant pathogens. Before biocontrol can become an important component of plant-disease management, it must be effective, reliable, consistent and economical. To meet these criteria, superior strains exhibiting improved biocontrol activity as well as an expanded host range must become available (Goldman et al., 1994; Harman et al., 1989). This goal requires extensive study of the molecular and cellular biology of the antagonistic interactions between the biocontrol agent and the phytopathogenic fungi. The acquired knowledge can be used for genetic manipulations to improve existing biocontrol agents.

Tricboderma spp. are common fungi, found in almost any soil. Members of this genus are antagonistic to other fungi, including plant-pathogenic species. Possible mechanisms involved in Trichoderma antagonism are: (a) antibiosis, whereby the fungi produce volatile or nonvolatile antibiotics (Dennis \& Webster, 1971a, b); (b) competition, when space or nutrients (i.e. carbon, nitrogen, microelements) are limiting factors (Schippers et al., 1987; Weller, 1988); (c) mycoparasitism, whereby Tricboderma attacks another fungus by excreting lytic enzymes (such as proteases, glucanases and chitinases) that enable it to degrade the latter's cell walls and utilize its nutrients (Chet, 1990; Cook \& Baker, 1983; Elad et al., 1982; Geremia et al., 1993; Ridout et al., 1988). Parasitism by Trichoderma spp. is destructive, causing the death of the host fungus (Barnett \& Binder, 1973). The cell-walldegrading enzymes are induced in Trichoderma during the parasitic interaction (Cherif \& Benhamou, 1990; Elad et al., 1983; Goldman et al., 1992; Limón et al., 1995; Lora et al., 1994), and have been shown to have a direct antifungal effect (Lorito et al., 1993). Via these mechanisms, Trichoderma antagonizes other fungi, thereby serving as a potential biological control agent of plant diseases (Baker, 1987; Chet, 1987, 1990).

\section{Hydrolytic enzymes of Trichoderma harzianum involved in mycoparasitism}

\section{Chitinases}

Chitin, an unbranched homopolymer of 1,4- $\beta$-linked $N$ acetyl-D-glucosamine (GlcNAc), is the second most abundant polymer in nature, after cellulose. It does not occur in plants, vertebrates or prokaryotes, but is abundant as a structural polymer in most fungi and insects, including those that are agricultural pests (Havukkala, 1991). Chitinases ate chitin-degrading enzymes, and their role in biological control and plantdefence mechanisms is now under extensive study (Broglie et al., 1991; Jach et al., 1995; Melcher et al., 1994; Schlumbaum et al, 1986; Shapira et al., 1989).

A considerable amount of recent research has been aimed 
Table 1. Summary of $T$. harzianum chitinolytic activities induced by chitin

\begin{tabular}{|c|c|c|c|c|}
\hline Designation & $\begin{array}{l}\text { Apparent mol. } \\
\text { mass (kDa) }\end{array}$ & Activity & Strain & Reference \\
\hline CHIT 102 & $102-118$ & $N$-Acetylglucosaminidase & $\begin{array}{l}\mathrm{TM} \\
39.1\end{array}$ & $\begin{array}{l}\text { Haran et al. (1995) } \\
\text { Ulhoa \& Peberdy (1991) }\end{array}$ \\
\hline CHIT 73 & 73 & $N$-Acetylglucosaminidase & $\begin{array}{l}\text { TM } \\
\text { P1 }\end{array}$ & $\begin{array}{l}\text { Haran et al. (1995) } \\
\text { Lorito et al. (1994) }\end{array}$ \\
\hline CHIT 52 & 52 & Endochitinase & 'IM & Haran et al. (1995) \\
\hline CHIT 42 & $40-42$ & Endochitinase & $\begin{array}{l}\text { CECT } 2413 \\
39.1 \\
\text { P1 }\end{array}$ & $\begin{array}{l}\text { De La Cruz et al. (1992) } \\
\text { Ulhoa \& Peberdy (1992) } \\
\text { Harman et al. (1993) }\end{array}$ \\
\hline CHIT 40 & 40 & Exochitinase (chitobiosidase) & $\mathrm{P} 1$ & Hatman et al. (1993) \\
\hline CHIT 33 & $33-37$ & Endochitinase & $\begin{array}{l}\text { CECT } 2413 \\
\text { TM }\end{array}$ & $\begin{array}{l}\text { De La Cruz et al. (1992) } \\
\text { Haran et al. (1995) }\end{array}$ \\
\hline CHIT 31 & $31-33$ & Endochitinase & $\begin{array}{l}\text { CECT } 2413 \\
\text { TM }\end{array}$ & $\begin{array}{l}\text { De La Cruz et al. (1992) } \\
\text { Haran et al. (1995) }\end{array}$ \\
\hline
\end{tabular}

at elucidating the chitinolytic system of Trichoderma spp. Most of these studies have been performed with $T$. barzianum, an effective biocontrol agent of several economically important plant-pathogenic fungi. T. barzianum attacks pathogens by excreting lytic enzymes, including glucanases, chitinases, proteases and lipases, which enable it to degrade host cell walls and thus reduce disease incidence (Chet et al., 1993; Elad et al., 1982; Lorito et al., 1993).

Chitinolytic enzymes were divided by Sahai \& Manocha (1993) into three principal types: (a) $1,4-\beta-N$-acetylglucosaminidases (EC 3.2.1.30), which split the chitin polymer into GlcNAc monomers in an exo-type fashion; (b) endochitinases (EC 3.2.1.14), which cleave randomly at internal sites over the entire length of the chitin microfibril; and (c) exochitinases (EC 3.2.1.14), which catalyse the progressive release of diacetylchitobiose in a stepwise fashion such that no monosaccharides or oligosaccharides are formed. Harman et al. (1993) termed an enzyme exhibiting this activity 'chitobiosidase'.

1,4- $\boldsymbol{\beta}$ - $\boldsymbol{N}$-Acetylg/ucosaminidases. Two $1,4-\beta-N$-acetylglucosaminidases have been reported to be excreted by $T$. barzianum. Ulhoa \& Peberdy (1991) described the purification of one of these from $T$. barzianum strain 39.1. They estimated its native molecular mass to be $118 \mathrm{kDa}$ by gel filtration, whereas by SDS-PAGE this value was $66 \mathrm{kDa}$. They therefore suggested that the active form was a homodimer. Haran et al. (1995) reported an $N$-acetylglucosaminidase of $102 \mathrm{kDa}$ (CHIT 102) which was expressed by $T$. barzianum strain TM when grown on chitin as the sole carbon source. They assumed it to be essentially the same enzyme described by Ulhoa \& Peberdy (1991) and the different estimates of its molecular mass were suggested to be the result of the different procedures used.

The other 1,4- $\beta-N$-acetylglucosaminidase, purified from T. barzianum strain $\mathrm{P} 1$, was estimated to be of $72 \mathrm{kDa}$ and had a $\mathrm{pI}$ of 4.6 (Lorito et al,, 1994). Haran et al. (1995) reported a $73 \mathrm{kDa}$ glucosaminidase (CHIT 73) that was expressed and excreted when T. barzianum strain TM was grown on chitin as the sole carbon source, but was not detected when the fungus was grown on glucose. The activity of CHIT 73 was found to be heat-stable.

Endochitinases. Four endochitinases have been reported to be expressed by $T$. barzianum. Haran et al. (1995) reported an endochitinase of $52 \mathrm{kDa}$ (CHIT 52). The enzyme was excreted into the growth medium when $T$. barzianum (strain TM) was grown on chitin as the sole carbon source, and it was highly sensitive to heat treatment.

An endochitinase of $42 \mathrm{kDa}$ (CHIT 42) was reported by De La Cruz et al. (1992), Haran et al. (1995) and Harman et al. (1993). The pI value of the endochitinase purified from $T$. barzianum strain P1 was approximately 3.9 and showed optimum activity at $\mathrm{pH} 4 \cdot 0$ (Harman et al., 1993). The $\mathrm{pI}$ value of CHIT 42 purified from T. barzianum strain CECT 2413 was $6 \cdot 2$ (De La Cruz et al., 1992). Ulhoa \& Peberdy (1992) reported a similiar endochitinase of $40 \mathrm{kDa}$ from $T$. harzianum strain 39.1, which exhibited optimum activity at $\mathrm{pH} 4 \cdot 0$.

Two endochitinases, estimated at $37 \mathrm{kDa}$ and $33 \mathrm{kDa}$, were expressed by $T$. barzianum strain CECT 2413 when grown on chitin as the sole carbon source. Their $\mathrm{PI}$ values were 4.6 and $7 \cdot 8$, respectively (De La Cruz et al., 1992). Haran et al. (1995) detected two similiar endochitinases of $33 \mathrm{kDa}$ (CHIT 33) and $31 \mathrm{kDa}$ (CHIT 31), expressed by $T$. barzianum strain TM.

Exochitinases (chitobiosidases). A chitobiosidase of $40 \mathrm{kDa}$ (CHIT 40) was reported to be secreted by $T$. barzianum strain P1 when grown on crab-shell chitin as the sole carbon source. This enzyme was glycosylated, and had a $\mathrm{pI}$ value of approximately 3.9 (Harman et al., 1993). A summary of the chitinolytic activities of $T$. harzianum is presented in Table 1.

The chitinolytic enzymes were induced and excreted during growth of $T$. barzianum strain TM on liquid 


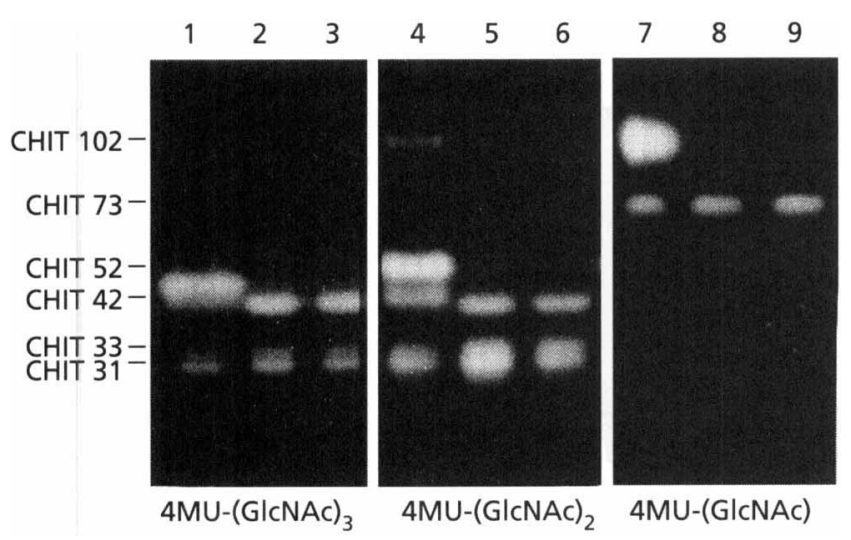

Fig. 1. Detection of extracellular chitinolytic activity of proteins produced by $T$. harzianum strain TM when grown on chitin as the sole carbon source. Lanes 1-9 contain $20 \mu \mathrm{g}$ extracellular protein, renatured following their separation by SDS-PAGE. Temperature treatments prior to loading on the gel were: lanes 1, 4 and 7, room temperature; lanes 2, 5 and $8,3 \mathrm{~min}$ at $55^{\circ} \mathrm{C}$; lanes 3,6 and $9,3 \mathrm{~min}$ at $100^{\circ} \mathrm{C}$. Chitinolytic activity was detected using 4-methylumbelliferyl $\beta$-D-N,N', $N^{\prime \prime}$-triacetylchitotriose [4-MU-(G|cNAC)$\left.)_{3}\right]$ (lanes 1-3), 4-methylumbelliferyl $\quad \beta-D-N, N^{\prime}$-diacetylchitobioside [4-MU(GlCNAC) ${ }_{2}$ ] (lanes $4-6$ ), or 4-methylumbelliferyl- $N$-acetyl- $\beta$-Dglucosaminide [4-MU-(GlcNAc)] (lanes 7-9) as the substrate (authors' unpublished data).

medium containing chitin as the sole carbon source (Fig. 1). Only CHIT 102 was expressed intracellularly at a low constitutive level when Trichoderma was grown on glucose, but none of the chitinolytic enzymes were secteted under these conditions (Haran et al., 1995).

To the best of our knowledge, two genes encoding endochitinases have been cloned. A cDNA clone of CHIT 42 was isolated from $T$. harzianum strain P1 by Hayes et al. (1994). The entire sequence, designated ThEn-42, consisted of $1554 \mathrm{bp}$, with an ORF encoding a putative protein of 424 amino acids. The deduced size of the mature endochitinase encoded by ThEn-42 was $42.66 \mathrm{kDa}$, which approximated to the measured value of $41 \mathrm{kDa}$. Garcia $e t$ al. (1994) also cloned a cDNA encoding $\mathrm{CHIT}$ 42. Analysis of the $\mathrm{N}$-terminal amino acid sequence of the chitinase, and comparison with that deduced from the nucleotide sequence, revealed post-translational processing of a putative signal peptide of 34 amino acids cleaved in two steps. Carsolio et al. (1994) isolated and sequenced a genomic clone of the same gene. Compatison of the genomic and cDNA sequences revealed the presence of three short introns $(56,69$ and $70 \mathrm{bp})$, a 209 bp 3' untranslated region, and a 240 bp promoter region. Expression of the cDNA clone in Escbericbia coli confirmed that the gene encodes a chitinase with activity on 4-methylumbelliferyl- $\beta$-D- $N, N^{\prime}, N^{\prime \prime}$-triacetylchitotriose. A gene for another endochitinase of $33 \mathrm{kDa}$ was recently cloned from $T$. barzianum strain CECT 2413 by Limón $e t$ al. (1995). The cDNA encodes a protein of 321 amino acids, which includes a putative signal peptide of 10 amino acids. The chit 33 gene appears as a single copy in the T. barzianum genome.

\section{Glucanases}

$\beta$-Glucans are homopolymers of D-glucose linked in a $\beta$ configuration. Some are relatively simple molecules, consisting of linear chains of glycosyl residues joined by a single linkage type, whereas others are more complex and can consist of a variety of linkages in either linear or branched chains. Although many fungi synthesize $\beta$ glucans, either extracellularly or cytoplasmically (Faro, 1972; Zevenhuizen \& Bartnicki-Garcia, 1970), they are generally located in the cell wall. The role of the fungal $\beta$ glucans is diverse, depending on their size, structure, physical and chemical properties, and most importantly, their location. 'The primary role of cell-wall $\beta$-glucans in fungi is as structural polymers, maintaining rigidity and conferring protection (Wessels \& Siestma, 1981). This is generally achieved through the assistance of other cellwail components, most commonly chitin, but also $\alpha$ glucans and assorted homo- and heteropolysaccharides. However, the nature and location of the wall $\beta$-glucans suggest that they may also be degraded and used as nutritional sources, after exhaustion of external nutrients, or for changes in the cell-wall composition during morphogenesis (Pitson et al., 1993).

The production of $\beta$-glucan-degrading enzymes is a characteristic attributed to a wide variety of organisms. Fungi are the main producers, with $\beta$-glucanases found in most isolates examined (Reese \& Mandels, 1963).

$\beta$-Glucanases can act via two possible mechanisms, identified by the products of hydrolysis: (a) exo- or endwise-splitting and (b) endo- or random-splitting (Duncan et al., 1956; Pitson et al., 1993). Exo- $\beta$-glucanases hydrolyse the $\beta$-glucan chain by sequentially cleaving glucose residues from the non-reducing end. Consequently, the sole hydrolysis product is a monomer, usually glucose (Pitson et al., 1993; Yamamoto \& Nevins, 1983). Fndo- $\beta$-glucanases cleave $\beta$-linkages at random sites along the polysaccharide chain, releasing smaller oligosaccharides (Pitson et al., 1993), and may be categorized into two groups according to the hydrolysis product: those principaliy releasing oligosaccharides during hydrolysis, and those rapidly producing glucose and disaccharides (Fleet \& Phaff, 1981). Synergistic action between at least two enzymes with different modes of action is common in fungi that degrade $\beta$-glucans (Copa-Patino et al., 1990).

$\beta$-Glucan-hydrolysing enzymes are classified according to the type of $\beta$-glucosidic linkage(s). Due to the abundance and importance of cellulose, the homopolymer of $1,4-\beta$ glucan, it is no surprise that most of the research has been concentrated on investigating $1,4-\beta$-glucans and their degradation. Functionally complete cellulase enzyme systems can be produced by a large variety of microorganisms, such as aerobic and anaerobic bacteria, and white-rot, soft-rot and anaerobic fungi. Among the bestcharacterized and most widely studied of these systems are the inducible cellulases of Trichoderma, particularly those of Trichoderma reesei. Kubicek et al. (1993) reviewed the cellulase system of Tricboderma spp., which consists of three general classes of enzymes: (a) 1,4- $\beta$-D-glucan cellobiohydrolases (CBH, EC 3.2.1.91), which cleave 
Table 2. Characterization of purified glucanases produced by $T$. harzianum

\begin{tabular}{|c|c|c|c|c|c|c|}
\hline \multirow[t]{2}{*}{ Strain } & \multirow{2}{*}{$\begin{array}{c}\text { Glucanase } \\
\text { type }\end{array}$} & \multirow{2}{*}{$\begin{array}{c}\text { Apparent } \\
\text { mol. mass } \\
(\mathrm{kDa})\end{array}$} & \multicolumn{3}{|c|}{ Optimum } & \multirow[t]{2}{*}{ Reference } \\
\hline & & & pI & $\mathrm{pH}$ & Temp. $\left({ }^{\circ} \mathrm{C}\right)$ & \\
\hline TMI 60622 & Exo-1,3- $\beta$ - & 31 & - & $4 \cdot 6$ & - & Kitamoto et al. (1987) \\
\hline Undefined & Exo-1,3- $\beta-$ & 40 & $7 \cdot 8$ & - & - & Dubourdieu et al. (1985) \\
\hline P1 & Endo-1,3- $\beta$ - & 78 & 6.2 & $4 \cdot 5-5 \cdot 5$ & 40 & Lorito et al. (1994) \\
\hline CECT 2413 & Endo-1,6- $\beta-$ & 43 & $5 \cdot 8$ & - & - & De La Cruz et al. (1995) \\
\hline
\end{tabular}

cellobiosyl units from the non-reducing end of cellulose chains; (b) endo-1,4- $\beta$-D-glucanases [EG, cellulase: 1,3$(1,3 ; 1,4)-\beta$-D-glucan 3(4) glucanohydrolase, EC 3.2.1.4], which cleave internal glucosidic bonds; and (c) 1,4- $\beta$-Dglucosidase (cellobiase; $\beta$-D-glucoside glucohydrolase, EC 3.2.1.21), which cleaves cello-oligosaccharides to produce glucose. At least two cellobiohydrolases (CBH I and CBH II), two or more endoglucanases (EG I and EG III), and one $\beta$-glucosidase operate synergistically in the degradation of cellulose by this fungus.

Since $1,3-\beta$-glucan is one of the main structural components of deuteromycete cell wall (Bartnicki-Garcia, 1968), the extracellular 1,3- $\beta$-glucanase has been thought to be involved in mycoparasitism (Ridout et al., 1988). Enzymes with activity against $1,3-\beta$-glucosidic linkages have been described in fungi, bacteria, actinomycetes, algae, molluscs and higher plants (Pitson et al., 1993). Although possibly less common, enzymes with activity against 1,6- $\beta$-glucosidic linkages have also been detected in many fungi and bacteria.

A number of Trichoderma isolates secrete 1,3- $\beta$ - and 1,6- $\beta$ glucanases (Del Rey et al., 1979). Along with chitinases and proteases, they are involved in the cell lysis of several phytopathogenic fungi during the mycoparasitic process (Elad et al., 1982). Since chitin and $\beta$-glucan are embedded in a matrix of amorphous material, successful cell-wall degradation may depend on the activity of more than one enzyme. Furthermore, chitin seems to be protected by $\beta$ glucan, and is not readily accessible to chitinases (Cherif $\&$ Benhamou, 1990). It is thus likely that chitinase activity is preceded by, or coincides with, the hydrolytic activity of other enzymes, especially $1,3-\beta$ - and $1,6-\beta$-glucanases. Simultaneous induction of both chitinase and 1,3- $\beta$ glucanase was reported in bean plants infected by Fusarium solani. Both enzymes were required for fungal cell-wall lysis and growth inhibition of the pathogen (Mauch et al., 1988a, b).

$\beta$-Glucanases from many fungi have been extensively characterized, and the results have led to an appreciation of their vastly different physicochemical properties (Pitson et al., 1993). A summary of characterized $\beta$-glucanases from T. barzianum is presented in Table 2 .

The importance of $\beta$-glucanases in plant-defence mechanisms against fungal attack has been very well established (Jach et al., 1995), and many glucanase-encoding genes have been identified and cloned. Although the involvement of glucanases in the mycoparasitic process and in biological control is well documented, direct evidence for their role has only recently been demonstrated. Lorito $e t$ al. (1994) purified a glucan 1,3- $\beta$-glucosidase from $T$. barzianum strain P1 to homogeneity. The purified enzyme inhibited spore germination and germ-tube elongation of Botrytis cinerea with $50 \%$-effective dose $\left(\mathrm{ED}_{50}\right)$ values of 94.5 and $90 \mu \mathrm{g} \mathrm{m}^{-1}$, respectively. For complete inhibition, $200-600 \mu \mathrm{g} \mathrm{ml}^{-1}$ were needed.

T. barzianum strain CECT 2413 was found to produce at least two 1,6- $\beta$-glucanases (De La Cruz et al., 1995). One of these $1,6-\beta$-glucanases, of $43 \mathrm{kDa}$, was purified to homogeneity. When the protein was combined with other $T$. barzianum cell-wall-degrading enzymes, such as $1,3-\beta-$ glucanases and chitinases, it hydrolysed filamentous fungal cell walls and inhibited the growth of the fungi tested (B. cinerea, Gibberella fujikuroi, Pbytopbthora syringae and Saccharomyces cerevisiae). To the best of our knowledge, only one gene encoding $\beta$-glucanase has been cloned from $T$. barzianum. Lora et al. (1995) described genomic and cDNA clones encoding the above 1,6- $\beta$-endoglucanase gene. The deduced protein sequence was found to have limited homology with other $\beta$-glucanases.

\section{Proteases}

Besides chitin and glucan, the skeleton of filamentous fungal cell walls contains lipids and proteins (Hunsley \& Burnett, 1970). Fungal proteases may therefore play a significant role in the cell-wall lysis that occurs during pathogen-host interactions. Sivan \& Chet (1989) found that pretreating hyphal walls of Fusarium oxysporum with proteolytic enzymes increases their susceptibility to lysis by the chitinase and 1,3- $\beta$-glucanase of T. barzianum. They suggested that a protein or protein-like constituent(s) is involved in the resistance of Fusarium cell walls to lytic enzymes. More recently, Geremia et al. (1993) identified an alkaline proteinase (Prb1) from T. barzianum strain IMI 206040. These authors suggested that Prb1 is involved in mycoparasitism, since it is induced by autoclaved mycelia, fungal cell-wall preparations or chitin, and repressed by glucose (Fig. 2). The gene (prb1) encoding this proteinase was cloned and characterized, and the induction of the enzyme was found to be due to an increase in the corresponding mRNA level. 


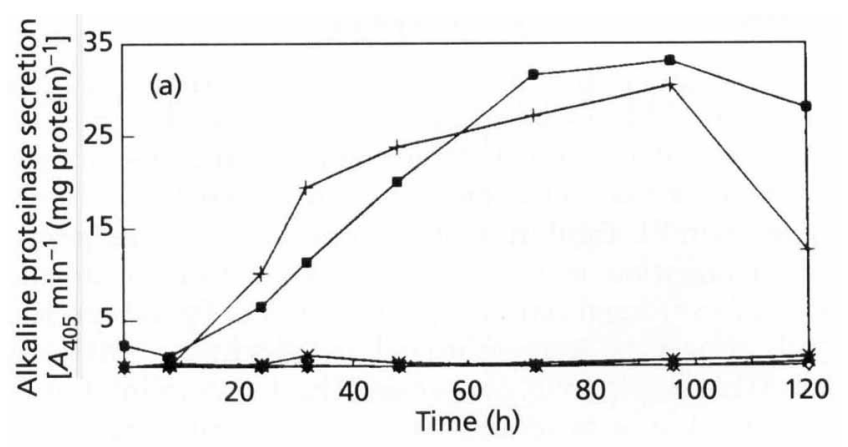

(b)

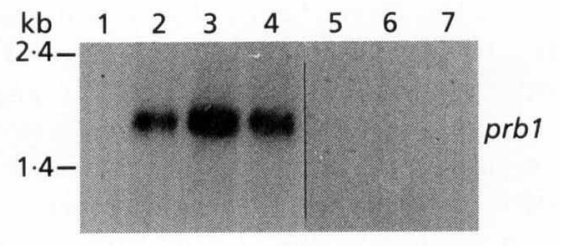

(c)

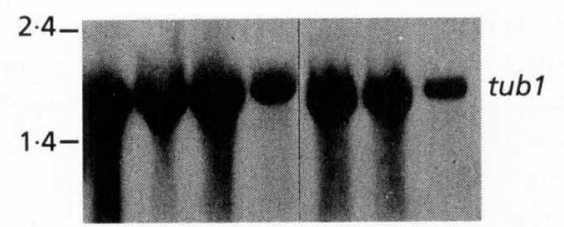

Fig. 2. Induction of $T$. harzianum alkaline proteinase and its encoding gene (prb1) during simulated mycoparasitism. (a) Secretion of the alkaline proteinase. $T$. harzianum was cultured in the presence of glucose $(x), R$. solani cell walls $(\square)$, chitin $(+), R$. solani cell walls and glucose $(\diamond)$, or chitin and glucose (*). Samples were collected at the indicated times. (b) and (c) Northern analysis. Total RNA extracted from mycelia cultured in the presence of $R$. solani cell walls without glucose (lanes 2-4) or with glucose (lanes 5-7) at $24 \mathrm{~h}$ (lanes 2 and 5), $48 \mathrm{~h}$ (lanes 3 and 6), and $72 \mathrm{~h}$ (lanes 4 and 7 ). RNA $(20 \mu \mathrm{g})$ from mycelia prior to induction was used as a control (lane 1). The RNA was electrophoresed and blotted using standard procedures. Induction of the prb1 was demonstrated by hybridization of a $500 \mathrm{bp}$ Pstl fragment of the proteinase-encoding gene (prb1) cDNA with the RNA blot (b). An internal control was performed (c) using the Trichoderma viride tubulin-1-encoding gene (tub1) CDNA as a probe (Geremia et al., 1993).

\section{Lytic enzymes of $T$. harzianum and biological control}

\section{Regulation during mycoparasitism}

Upon contact with the host, $T$. barzianum mycelium coils around or grows along the host hyphae and forms hooklike structures that aid in penetrating the host's cell wall (Elad et al., 1983). In T. harzianum strain T-Y, this reaction has been found to be rather specific, and lectincarbohydrate interactions were assumed to mediate the recognition and attachment between Trichoderma and soil-borne plant-pathogenic fungi. Recently, Inbar \& Chet (1994) isolated and purified a new lectin from the culture filtrate of the soil-borne plant pathogenic fungus Sclerotium rolfsii. The authors developed a biomimetic system based on nylon fibres designed to imitate the pathogen hyphae. The purified lectin, bound to the surface of these nylon fibres, specifically induced mycoparasitic (a)
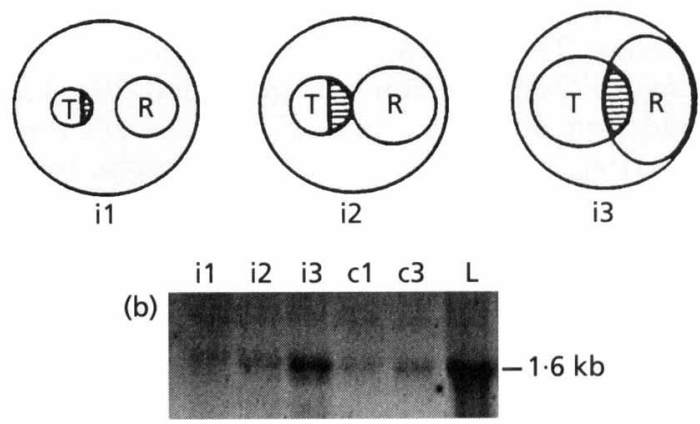

(c)

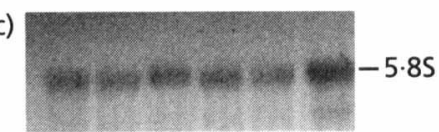

Fig. 3. Expression of $T$. harzianum endochitinase gene (ech-42) during mycoparasitism. $T$. harzianum, strain IMI 206040, and $R$. solani were grown in dual culture and mycelia were collected at different stages of the interaction. (a) Schematic representation of the three different stages at which the samples (shaded area) were taken. The outer circle represents the plate; the two inner circles represent the colonies of $R$. solani (R) and T. harzianum (T). i1, interaction before physical contact; i2, interaction at the first direct contact; 3 , when Trichoderma is overgrowing Rhizoctonia. (b) Northern blot analysis of the expression of ech-42, using a cDNA clone of ech42 as the probe. $i 1, \mathrm{i} 2$ and $\mathrm{i} 3$ are as in (a). RNA from control cultures of $T$. harzianum grown in the absence of $R$. solani are in lanes $\mathrm{Cl}$ and $\mathrm{C} 3$ (in the dark, equivalent to $\mathrm{i} 1$ and $\mathrm{i} 3$ ) and $\mathrm{L}$ (with light, equivalent to c1). Migration position of ech-42 mRNA and its size are indicated. (c) An internal control was performed using human 5.85 rRNA as the probe. Samples were as in (b). Migration position of the rRNA is indicated (Carsolio et al., 1994).

behaviour in $T$. harzianum. The fungus formed tightly adhering coils, which were significantly more frequent with the purified-agglutinin-treated fibres than with untreated controls, or with those treated with nonagglutinating extracellular proteins from Scler. rolfsii. Inbar \& Chet (1995) further showed that the induction of a $102 \mathrm{kDa}$ glucosaminidase (CHIT 102) is an early event elicited by the recognition signal (i.e. lectin-carbohydrate interactions). When $T$. barzianum was grown in dual culture with Scler. rolfsii, CHIT 102 activity was the first to be induced. As the interaction proceeded, the activity of CHIT 102 diminished concomitantly with the appearance of another glucosaminidase of $73 \mathrm{kDa}$ (CHIT 73).

Carsolio et al. (1994) reported strong enhancement of CHIT 42 expression during interactions of T. barzianum strain IMI 206040 with Rbizoctonia solani (see Fig. 3). Schirmböck et al. (1994) reported the induction of a $40 \mathrm{kDa}$ chitobiosidase, a $41 \mathrm{kDa}$ endochitinase and a 1,3$\beta$-glucanase in T. barzianum strain A TCC 36042 when the fungus was grown on cell walls of $B$. cinerea. These enzymes were not detected when $T$. barzianum was grown on glucose. De La Cruz et al. (1993) also reported the induction of chitinase when $T$, barzianum strain CECT 2413 was grown on cell walls of $B$. cinerea.

Lora et al. (1994) investigated changes in gene-expression 
patterns elicited by chitin in the same strain of $T$. barzianum. They speculated that oligosaccharides containing GlcNAc, which are generated by the partial degradation of fungal cell walls, act as elicitors which might trigger a general antifungal response in $T$. barz ${ }^{i-}$ anum. However, Limón et al. (1995) reported differences in the gene expressions of CHIT 42 and CHIT 33, suggesting independent regulation of each of these endochitinases.

Maximal 1,3- $\beta$-and 1,6- $\beta$-glucanase-specific activities were detected in media supplemented with purified cell walls from either $B$, cinerea or Sacc. cerevisiae, or pustulan $(1,6-\beta$ glucan) and nigeran (1,3- $\alpha$-glucan alternating with $1,4-\alpha-$ glucan) (De La Cruz et al., 1993). However, Tangarone et al. (1989) reported excretion of glucanase from Trichoderma longibrachiatum grown on a D-glucose medium, and De Ja Cruz et al. (1993) and Lorito et al. (1994) reported excretion of the enzyme from $T$. barzianum grown on a chitin medium. These results indicate that $1,3-$ $\beta$-glucan is not required for glucanase synthesis. A possible explanation is that glucanases are produced constitutively, due to their involvement in fungal growth and differentiation, as has previously been suggested by Pitson et al. (1993). Alternatively, simultaneous induction with chitinolytic enzymes may occur. Concurrent induction of chitinases and glucanases has been described in plants as a response to infection by microbial pathogens. The two enzymes have also been shown to exhibit synergistic antifungal activity (Lorito et al., 1994). Since the substrates of both classes of enzymes frequently occur together in nature, as in fungal cell walls, a combined induction of glucosidases and chitinases may be ecologically relevant.

The activity of an alkaline proteinase gene ( $p r b 1$ ) was suggested by Geremia et al. (1993) to play a key role in mycoparasitism. Flores et al. (1996) determined its induction in mycoparasitic-like situations. They found that this gene was induced as early as $4 \mathrm{~h}$ after the fungus was transferred to cultures containing $R$. solani cell walls. To establish whether the induction observed with cell walls correlated with the actual phenomenon (fungus-fungus interaction), the authors performed direct confrontation assays between T. barzianum strain IMI 206040 and R. solani. Induction of prb1 mRNA was observed in the presence of $R$. solani.

In an attempt to identify genes specifically expressed by the same strain of $T$. barzianum during growth on cell walls of $R$. solani, Vasseur et al. (1995) used differential screening of an induced cDNA library. They reported the expression of two cDNA clones that encode putative mycoparasitism-related proteins of 62853 and $37010 \mathrm{Da}$. They suggested the use of this methodology for the identification of genes involved in mycoparasitism.

These results suggest that a recognition event initiates a set of specific mycoparasitic responses, consisting of morphological as well as biochemical changes: coiling and appressorium formation, induction of unique combinations of chitinolytic enzymes, and induction of other cell-wall-hydrolysing enzymes such as glucanases and proteases.

\section{Synergism of hydrolytic enzymes}

The antifungal activity of cell-wall-degrading enzymes has recently been studied by several authors. Lorito $e t a l$. (1993) tested antifungal activity of purified endochitinase and exochitinase (chitobiosidase) produced by $T$. barzianum strain P1. Inhibition of spore germination and germtube elongation were used as bioassays to evaluate the level of antifungal activity against different fungal species. Both processes were inhibited in all chitin-containing fungi tested, except T. barzianum. The degree of inhibition was found to be proportional to the levels of chitin in the cell wall of the target fungi. These chitinolytic enzymes appeared to be biologically more active than enzymes from other sources and more effective against a wider range of fungi. Combining the activities of the endochitinase and exochitinase (chitobiosidase) resulted in a synergistic increase in antifungal activity. The authors suggested that mixtures of hydrolytic enzymes with complementary modes of action may be required for maximum efficacy and that correct combinations of enzymes may increase in vitro antifungal activity. Lorito et al. (1994) reported the purification of two additional cellwall-degrading enzymes from the same strain of $T$. barzianum: an $N$-acetyl- $\beta$-glucosaminidase and a glucan $1,3-\beta$-glucosidase. Using the above bioassays, they found a synergistic inhibitory effect on $B$. cinerea spore germination and germ-tube elongation when two, three or four enzymes were applied together. The highest level of antifungal activity was obtained when a solution containing all four cell-wall-degrading enzymes was used.

A similar phenomenon has been reported in plants. Using transgenic tobacco, Jach et al. (1995) showed that when a heterologous class-II chitinase was co-expressed with a heterologous class-II 1,3- $\beta$-glucanase, the transgenic tobacco plant exhibited significantly enhanced protection against fungal attack as compared to protection levels obtained when either heterologous gene was expressed alone.

\section{Synergism of lytic enzymes and other antifungal compounds}

Schirmböck et al. (1994) reported the parallel formation and synergism of hydrolytic enzymes and peptaibol antibiotics, formed by $T$. barzianum strain ATCC 36042 when grown on cell walls of $B$. cinerea. Purified trichorzianines $A_{1}$ and $B_{1}$, as well as purified exochitinase (chitobiosidase), endochitinase, or glucan $1,3-\beta$-glucosidase, inhibited spore germination and hyphal elongation only at concentrations higher than those observed in culture supernatants. However, when the enzymes and the peptaibols were tested together, a synergistic antifungal interaction was observed and the $\mathrm{ED}_{50}$ values were in the range of those determined in the culture supernatants. When endochitinase and exochitinase (chitobiosidase) from $T$, barzianum were combined with a biocontrol strain of Enterobacter cloacae, antifungal activities were increased synergistically (Lorito et al., 1993).

Synergistic activity might serve as a tool to reduce the use of hazardous chemical fungicides. A synergistic effect was 
found when commercial fungicides against $B$. cinerea wete mixed with any of the chitinolytic or glucanolytic enzymes, and antifungal efficacy was significantly enhanced (Lorito et al., 1994). Dose-response curves were determined for each combination of toxin and enzyme, and in all cases the $\mathrm{ED}_{50}$ values of the mixtures were substantially lower than those of each compound alone. The level of synergism appeared to be higher when enzymes were combined with toxins having primary sites of action associated with membrane structure, as compared to pesticides having multiple or cytoplasmic sites of action. The use of hydrolytic enzymes to enhance the antifungal ability of fungitoxic compounds could reduce the impact of some chemical pesticides on plants and animals.

\section{Heterologous genes as a tool for improving biocontrol activity}

Successful biocontrol is dependent upon several factors, including the development of superior biocontrol strains (Chet $e$ t al., 1993). To this aim, one of the most attractive approaches is the production of transgenic strains with genetic components conferring improved antifungal features.

Cell-wall-degrading enzymes have been shown to be strong inhibitors of fungal growth and survival, and can therefore be used to improve biocontrol activities. Shapira et al. (1989) demonstrated the involvement of chitinase in the control of Scler, rolfsii by genetic engineering techniques: the gene chi $A$, encoding the major chitinase produced by Serratia marcescens, was cloned into E. coli. The enzyme produced by the cloned gene caused rapid and extensive bursting of Scler. rolfsii hyphal tips. This chitinase preparation was also effective in reducing the incidence of diseases caused by $S c l e r$. rolfsii in bean and by $R$. solani in cotton, under greenhouse conditions.

Sitrit et al. (1993) introduced the chiA gene from Serr. marcescens into the plant symbiont Sinorbizobium (Rbizobium) meliloti, which colonizes alfalfa root nodules. They showed that Sinorbizobium colonies hatbouting the chitinase gene exhibit antifungal activity during symbiosis on alfalfa roots. The importance of chitinolytic activity in biocontrol has been demonstrated by Chernin et al. (1995). Chitinolytic strains of the bacterium Enterobacter agglomerans decreased the incidence of disease caused by $R$. solani in cotton by $64-86 \%$. In contrast, Tn 5 mutants of the bacterium, which were deficient in chitinolytic activity, were unable to protect the plants against the disease.

Enhancement of biocontrol activity by $T$. barzianum (T35) was attempted by Haran et al. (1993). An Serr. marcescens chitinase gene was introduced into the $T$. barzianum genome, under the control of a $35 \mathrm{~S}$ constitutive promoter from cauliflower mosaic virus. The authors expected constitutive elevation of extracellular lytic activity to improve the natural capability of $T$. harzianum to attack pathogens, thereby enabling its consequent use as a superior biocontrol agent. T. barzianum protoplasts were co-transformed using two plasmids: (a) pSL3ChiAII, containing a bacterial chitinase gene from Serr. marcescens under the control of a constitutive viral promoter and (b) p3SR2, encoding acetamidase cloned from Aspergillus nidulans, as a marker for selection after transformation. When grown on glucose, the T. barzianum transformants produced and excreted a protein that was detected by SDS-PAGE as a major band of $58 \mathrm{kDa}$, the size of the Serr. marcescens-produced chitinase. The transformants expressed significantly higher chitinase activity than the recipient (wild-type), suggesting that the signals for expression of the introduced gene had been recognized by $T$. harzianum. However, the higher chitinase activity occurred only when the transformants were grown on glucose. When grown in the presence of chitin, both transformants showed lower chitinase activity than the wild-type. Western blot analysis of the proteins excreted by the transformants in the presence of chitin revealed two species of proteins reacting specifically with the polyclonal antibodies against the Serr. marcescens chitinase (ChiA). These proteins were of 40 and $18 \mathrm{kDa}$, relative to the $58 \mathrm{kDa}$ protein of Serr. marcescens. These results suggest that under non-inductive conditions, the transformants produced the approximately $58 \mathrm{kDa}$ chitinase encoded by the introduced $c b i A$ gene, and that induction by chitin caused cleavage of this protein into two fragments of 40 and $18 \mathrm{kDa}$. The cleavage of foreign proteins by host proteases has previously been reported in Sacc. cerevisiae (Bonnet \& Spahr, 1990).

The natural chitinolytic system of T. barzianum is composed of at least seven distinct enzymes (Table 1). As a result of the cleavage event, additional foreign fragments of 40 and $18 \mathrm{kDa}$ were excreted by the transformed $T$. barzianum during induction. These fragments could have interfered with the natural excretion of the native chitinases, explaining the observed decrease in the chitinase activity of the transformants under inductive conditions.

Fitness evaluations showed that the transformants were not biologically inferior to wild-type $T$. barzianum in biomass production, growth rate or sporulation. Antagonism evaluation using dual cultures showed that the transformants overgrow the pathogen Scler. rolfsii at the same rate as wild-type $T$. harianum. However, while overgrowing the pathogen, the transformants produced wider clear lytic zones relative to the wild-type, probably as a consequence of their higher constitutive chitinase activity (Fig. 4). The higher activity of the chitinase excreted by $T$. harzianum transformants could protect germinating seedlings from certain soil-borne pathogens. Constitutive expression could produce extracellular lytic activity early on, whereas induced enzymes are produced only after the biocontrol agent interacts with the target pathogenic fungus.

The promoters of constitutive genes have proven themselves to be useful parts of expression vectors for genetic engineering in different organisms. Whereas promoters isolated from other organisms can sometimes prove useful, one can never be sure that they will work similarly 


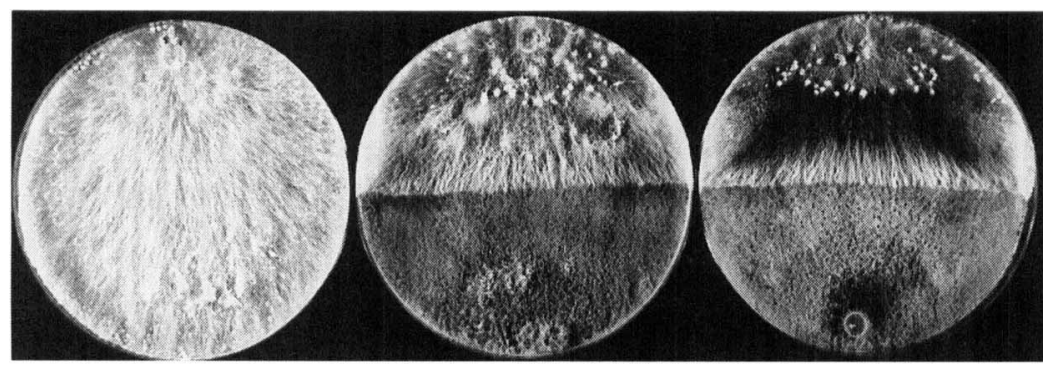

Fig. 4. Mycoparasitic interactions of $T$. harzianum (wild-type) and a transgenic strain of $T$. harzianum expressing a Serr. marcescens chitinase gene (chiA), with Scler. rolfsii in dual cultures. The Serratia chitinase gene was introduced into the $T$. harzianum genome, under the control of the 355 promoter from cauliflower mosaic virus, and was constitutively expressed by the transgenic strain. Left to right: Scler. rolfsii; dual cultures of $T$. harzianum (wild-type) (middle plate) and a transgenic strain of $T$. harzianum (right plate), respectively (both on the lower half of the plate), with Scler. rolfsit (upper half), $7 \mathrm{~d}$ after contact (Haran et al., 1993)

in all physiological or developmental states of the heterologous host. Based on differential screening of an induced cDNA library, Goldman et al. (1994) isolated constitutively expressed cDNA clones of $T$. barzianum. One of these cDNA clones corresponded to a gene ( $\operatorname{cob} 4)$ that encodes a novel serine + alanine-rich protein. Northem (RNA) blot analysis demonstrated that cob4 was expressed during growth when glucose or cell walls of a phytopathogenic fungus were provided as the carbon soutce. They suggested that constitutively expressed genes could provide reliable promoters useful for genetic manipulations.

Most of the work on T. harzianum as a biocontrol agent has been performed with phytopathogenic fungi which contain mainly chitin and $\beta$-glucan as cell-wall components. However, plant-pathogenic oomycetes contain cellulose as the main cell-wall component (BartnickiGarcia, 1968). Migheli et al. (1994) attempted a different way of improving Tricboderma as a biocontrol agent by using the enzyme 1,4- $\beta$-endoglucanase. Hypercellulolytic strains of $T$. longibracbiatum were obtained by co-transformation of plasmid pTLEG12, which contains the eglt gene for the 1,4- $\beta$-endoglucanase of $T$. longibracbiatum and plasmid pAN7-1, which confers hygromycin B resistance, for selection after transformation (Sanchez-Torres et al., 1994). The transformants were tested for their ability to reduce Pythium damping-off on cucumber seedlings, and were shown to be significantly more effective in controlling the disease than the wild-type (disease incidence was reduced from 60 to $28 \%$ ). These preliminary results suggest that cellulase activity may be involved in the biocontrol of Pythium ultimum by $T$. longibracbiatum.

Geremia et al. (1993) cloned a gene encoding the basic proteinase prb1 from T. barzianum strain IMI 206040, and suggested that it plays a key role in mycoparasitism. Flores et al. (1996) attempted to increase the $p r b 1$ gene dosage by introducing multiple copies of $p r b 1$ into the Trichoderma genome. Integration occurred as multiple copies arranged in tandem, as has been previously described (Goldman et al., 1990; Hetrera-Estrella et al., 1990). The number of copies was estimated at 2-6 in the various transformants obtained. Densitometric analysis of RNA expression by Northern, and protein expression by
Western analyses, indicated that the levels of $p r b 1 \mathrm{mRNA}$ and protease secreted by the transformants were up to 17and 20-fold higher than in the wild-type strain, respectively. However, analysis of prb1 mRNA and Prb1 protein production by each of the transformants indicated that high prb1 mRNA production does not always result in high protein production. The various transformants showed a gradient of proteinase protein production. The successful overexpression of the prb1 gene, driven by its own promoter, led the authors to test the effectiveness of the transformants as biocontrol agents (Flores et al., 1996). Greenhouse experiments were performed in which the transformed T. barzianum strains were used to protect cotton seedlings from R, solani. An up-to-fivefold increase was observed in the biocontrol efficacy of the transformed strains, as compared to the wild-type. However, the best protection was provided by a strain which produced only an intermediate level of proteinase protein. The authors suggested that extreme levels of proteinase protein might cause degradation of other enzymes which are important in the mycoparasitic process. These results demonstrated that the introduction of multiple copies of $p r b 1$ improves the biocontrol activity of $T$. barrianum and showed the importance of the proteinase Prb1 in biological control.

\section{Summary}

The direct mycoparasitic activity of fungi of the genus Trichoderma has been proposed as one of the major mechanisms involved in their antagonistic activity against phytopathogenic fungi. Multiple enzyme systems are involved in the parasitic interactions. The chitinolytic system, as well as the glucanolytic system, are composed of enzymes with different modes of action. Only one alkaline proteinase has so far been found to be involved in the process.

The creation of gene-disrupted strains of T. harzianum has not been reported to date. Thus, the significance of the individual gene products in the mycoparasitic process was not assessed. Ilowever, in vitro studies using these enzymes, purified from $T$. barzianum, have shown their direct antifungal effect. Synergism of this effect was reported when combinations of the various enzymes were used. 
As a commercial product, wild-type $T$. harzianum preparations are currently making their way to the market. Some formulations are applied as potting mixtures in greenhouses, as seed-coating treatments or as foliar applications. However, their use in commercial agriculture is not yet widespread because, to date, the control of plant diseases with Trichoderma has not been as effective and reliable as with synthetic fungicides. Further studies of the right ecological niches and of the mechanisms involved in its mycoparasitic behaviour will improve our ability to use this fungus for effective plant-disease control.

The possibilities for improving biocontrol activity by $T$. barzianum using genetic manipulation techniques are promising. The early studies with transgenic $T$. barzianum transformed to produce increased amounts of specific proteins are encouraging, since even with these preliminary systems, positive results have been obtained. Future research should focus on the development of strains expressing 'multigene' combinations while preserving the intrinsic vigour and the ecological competence of the fungus. Once transgenic $T$. barzianum strains capable of producing highly efficient synergistic combinations of enzymes are produced, much better disease control should be obtained. Transgenic Trichoderma therefore offers the potential of substantially reducing the quantity of chemical fungicides required to produce disease-free plants.

\section{Acknowledgements}

The authors wish to thank M. Van Montagu for providing us with Fig. 2, which demonstrates the induction of prb1 during growth of $T$. barzianum on different carbon sources. We would like to thank A. Herrera-Estrella for providing us with Fig. 3, which shows the induction of CHIT 42 during the mycoparasitic interaction between $T$. harzianum and R. solani.

The research for this review was supported in part by the Binational Agricultural Research and Development Fund (BARD) and by the the Eshkol Fund of the Ministry of Science and Technology.

\section{References}

Baker, K. F. (1987). Evolving concepts of biological control of plant pathogens. Amn Rev Pbytopathol 25, 67-85.

Barnett, H. L. \& Binder, F. L. (1973). The fungal host-parasite relationship. Annu Rev Pbytopatbol 11, 273-292.

Bartnicki-Garcia, S. (1968). Cell wall chemistry, morphogenesis and taxonomy of fungi. Annu Rev Microbiol 22, 87-109.

Bonnet, D. \& Spahr, P. F. (1990). Rous sarcoma virus expression in Saccharomyces cerevisiae. Processing and membrane targeting of the gag gene product. I Virol 64, 5628-5632.

Broglie, K., Chet, I., Holliday, M., Cressman, R., Biddle, P., Knowlton, 5., Mauvais, J. C. \& Broglie, R. (1991). Transgenic plants with enhanced resistance to the fungal pathogen Rbizoctonia solani. Science 254, 1194-1197.

Carsolio, C., Gutierrez, A., Jimenez, B., Van Montagu, M. \& Herrera-Estrella, A. (1994). Characterization of $e c h-42$, a Trichoderma barzianum endochitinase gene expressed during mycoparasitism. Prac Nall Acad Sci US A 91, 10903-10907.

Cherif, M. \& Benhamou, N. (1990). Cytochemical aspects of chitin breakdown during the parasitic action of Trichoderma spp. on Fusarium oxysparum f. sp. radicis-lycopersici. Phytopathology 80, 14061414.

Chernin, L., Ismailov, Z., Haran, S. \& Chet, I. (1995). Chitinolytic Enterobacter aggiomerans antagonistic to fungal plant pathogens. $J$ Appl Environ Microbiol 61, 1720-1726.

Chet, I. (1987). Trichoderma: application, mode of action, and potential as a biocontrol agent of soilborne plant pathogenic fungi. In Innowative Approaches to Plant Disease Control (Series in Ecological and Applied Microbiology), pp. 137-160. Edited by I. Chet. New York: J. Wiley \& Sons.

Chet, I. (1990). Biological control of soil-borne plant pathogens with fungal antagonists in combination with soil treatments. In Biological Control of Soil-Borne Plant Pathogens, pp. 15-25. Edited by D. Hornby. Wallingford: CAB International.

Chet, I., Barak, Z. \& Oppenheim, A. (1993). Genetic engineering of microorganisms for improved biocontrol activity. In Biotechnological Prospects of Plant Disease Control, pp. 211-235. Edited by I. Chet. New York: Wiley-Liss.

Cook, R. S. \& Baker, K. F. (1983). The Nature and Practice of Biological Control of Plant Pathogens. St Paul, MN: The American Phytopathological Society.

Copa-Patino, J. L., Rodriquez, J., Reyes, F. \& Perez-Leblic, M. I. (1990). Effect of $\beta$-glucanases on Penicilizum oxalicum cell wall fractions. FEMS Microbiol Lett 70, 233-240.

De La Cruz, J., Hidalgo-Gallego, A., Lora, J. M., Benitez, T., PintorToro, J. A. \& Llobell, A. (1992). Isolation and characterization of three chitinases from Trichoderma barzianum. Eur I Biochem 206, 859-867.

De La Cruz, J., Rey, M., Lora, J. M., Hidalgo-Gallego, A., Dominguez, F., Pintor-Toro, J. A., Llobell, A. \& Benitez, T. (1993). Carbon source control on $\beta$-glucanases, chitobiase and chitinase from Trichoderma barzianum. Arch Microbiol 159, 316-322.

De La Cruz, J., Pintor-Toro, J. A., Benitez, T. \& Llobell, A. (1995). Purification and characterization of an endo- $\beta-1,6$-glucanase from Trichoderma barzianum that is related to its mycoparasitism. I Bacteriol 177, 6937--6945.

Del Rey, F., García-Acha, I. \& Nombela, C. (1979). The tegulation of $\beta$-glucanase synthesis in fungi and yeast. $J$ Gen Micrabiol 110, 83-89.

Dennis, C. \& Webster, J. (1971a). Antagonistic properties of species-groups of Trichoderma. I. Production of non-volatile antibiotics. Trans Br Mycol Soc 57, 25-39.

Dennis, C. \& Webster, J. (1971b). Antagonistic properties of species-groups of Trichoderma. II. Production of volatile antibiotics. Trans Br Mycol Soc 57, 41-48.

Dubourdieu, D., Desplanques, C., Villettaz, J. C. \& RibereauGayon, P. (1985). Investigations of an industrial $\beta$-D-glucanase from Tricboderma barzianum. Carbobydr Res 144, 277-287.

Duncan, W. A. M., Manners, D. J. \& Ross, A. G. (1956). Enzyme systems in marine algae. The carbohydrase activities of unfractionated extracts of Cladophora rupestris, Laminaria digitata, Rbodimenia palmata and Uha lactwca. Biochem J 63, 44-51.

Elad, Y., Chet, I. \& Henis, Y. (1982). Degradation of plant pathogenic fungi by Trichoderma barzianum. Can J Microbiol 28, 719-725.

Elad, Y., Chet, I., Boyle, P. \& Henis, Y. (1983). Parasitism of Tricboderma spp. on Rhizoctonia solani and Sclerotium rolfsiiscanning electron microscopy studies and fluorescence microscopy. Pbytopatbology 73, 85-88.

Faro, S. (1972). A soluble beta-1,3-glucan found in selected genera of oomycetes. J Gen Microbiol 72, 393.394. 
Fleet, G. H. \& Phaff, H. J. (1981). Fungal glucans - structure and metabolism. In Encyclopedia of Plant Pbysiology, 13B, pp. 416-440. Edited by W. Tanner \& F. A. Loewus. Berlin: Springer-Verlag.

Flores, A., Chet, I. \& Herrera-Estrella, A. (1996). Improved biocontrol activity of Trichoderma barzianum strains by overexpression of the proteinase encoding gene prb1. Curr Genet (in press).

Garcia, I., Lora, J. M., De La Cruz, J., Benitez, T., Llobell, A. \& Pintor-Toro, J. A. (1994). Cloning and characterization of a chitinase (CHIT42) cDNA from the mycoparasitic fungus Tricboderma barzianum. Curr Genet 27, 8389.

Geremia, R., Goldman, G. H., Jacobs, D., Ardiles, W., Vila, S. B., Van Montagu, M. \& Herrera-Estrella, A. (1993). Molecular characterization of the proteinase-encoding gene, $p r b 1$, related to mycoparasitism by Trichoderma harzianum. Mol Microbiol 8, 603-613.

Goldman, G. H., Van Montagu, M. \& Herrera-Estrella, A. (1990). Transformation of Trichoderma harzianzm by high-voltage electric pulse. Curr Genet 17, 169-174.

Goldman, H. G., Geremia, R. A., Caplan, A. B., Vila, S. B., Villarroel, R., Van Montagu, M. \& Herrera-Estrella, A. (1992). Molecular characterization and regulation of the phosphoglycerate kinase gene from Trichoderma viride. Mol Microbiol 6, 1231-1242.

Goldman, H. G., Hayes, C. \& Harman, G. E. (1994). Molecular and cellular biology of biocontrol by Trichoderma spp. Trends Biotecbnol $12,478-482$.

Haran, S., Schickler, H., Pe'er, S., Logemann, S., Oppenheim, A. \& Chet, I. (1993). Increased constitutive chitinase activity in transformed Trichoderma harzianum. Biol Control 3, 101-108.

Haran, S., Schickler, H., Oppenheim, A. \& Chet, I. (1995). New components of the chitinolytic system of Trichoderma harzianum. Mycol Res 99, 441-446.

Harman, G. E, Taylor, A. G. \& Stasz, T. E. (1989). Combining effective strains of Trichoderma harz̧ianum and solid matrix priming to provide improved biological seed treatments systems. Plant Dis 73, 631-637.

Harman, G. E., Hayes, C. K., Lorito, M., Broadway, R. M., Di Pietro, A., Peterbauer, C. \& Tronsmo, A. (1993). Chitinolytic enzymes of Trichoderma harzianum: purification of chitobiosidase and endochitinase. Pbylopathology 83, $313-318$.

Havukkala, I. (1991). Chitinolytic enzymes and plant pests. In Biotechnology in the Philippines Towards the Year 2000, pp. 127-140. Proceedings of the Second Asiz-Pacific Biotechnology Congress, edited by L. L. Ilag \& A. K. Raymundo. Los Banos: SEARCA, University of the Philippines.

Hayes, C. K., Klemsdal, S., Lorito, M., Di Pietro, A., Peterbauer, C., Nakas, J. P., Tronsmo, A. \& Harman, G. E. (1994). Isolation and sequence of an endochitinase gene from a cDNA library of Tricboderma barzianum. Gene 138, 143-148.

Herrera-Estrella, A., Goldman, G. H. \& Van Montagu, M. (1990). High efficiency transformation system for the biocontrol agents Trichoderma spp. Mol Microbiol 4, 839-843.

Hunsley, D. \& Burnett, J. H. (1970). The ultrastructural architecture of the walls of some hyphal fungi. J Gen Microbiol 62, 203-218.

Inbar, J. \& Chet, I. (1994). A newly isolated lectin from the plant pathogenic fungus Silerotim rolfsii: purification, characterization and role in mycoparasitism. Microbiology 140, 651-657.

Inbar, J. \& Chet, I. (1995). The role of recognition in the induction of specific chitinases during mycoparasitism by Tricboderma barzianum. Microbiology 141, 2823-2829.

Jach, G., Gornhardt, B., Mundy, J., Logemann, J., Pinsdorf, E., Leah, R., Schell, J. \& Mass, C. (1995). Enhanced quantitative resistance against fungal disease by combinatorial expression of different barley antifungal proteins in transgenic tobacco. Plant $J \mathbf{8}$, 97-109.

Kitamoto, Y., Kono, R., Shimotori, M. \& Ichikawa, Y. (1987) Purification and some properties of an exo- $\beta$-1,3-glucanase from Trichoderma barzianum. Agric Biol Chem 51, 3385-3386.

Kubicek, C. P., Messner, R., Gruber, F., Mach, R. L. \& KubicekPranz, E. M. (1993). The Trichoderma cellulase regulatory puzzle: from the interior life of a secretory fungus. Envyme Microb Technol $15,90-99$.

Limón, M. C., Lora, J. M., Garcia, I., De La Cruz, J., Llobell, A., Benitez, T. \& Pintor-Toro, J. A. (1995). Primary structure and expression pattern of the $33-\mathrm{kDa}$ chitinase gene from the mycoparasite fungus Trichoderma barzianum. Curr Genet 28, 478-483.

Lora, J. M., De La Cruz, J., Benitez, T., Llobell, A. \& Pintor-Toro, J. A. (1994). A putative catabolite-repressed cell wall protein from the mycoparasitic fungus Tricboderma barzianum. Mol Gen Genet 242, 461-466.

Lora, J. M., De La Cruz, J., Llobell, A., Benitez, T. \& Pintor-Toro, J. A. (1995). Molecular characterization and heterologous expression of an endo- $\beta-1,6$-glucanase gene from the mycoparasitic fungus Trichoderma barzianum. Mol Gen Genet 247, 639-645.

Lorito, M., Harman, G. E., Hayes, C. K., Broadway, R. M., Woo, S. L. \& Di Pietro, A. (1993). Chitinolytic enzymes produced by Trichoderma barzianum. II. Antifungal activity of purified endochitinase and chitobiosidase. Pbytopathology 83, 302-307.

Lorito, M., Hayes, C. K., Di Pietro, A., Woo, S. L. \& Harman, G. E. (1994). Purification, characterization, and synergistic activity of a glucan 1,3- $\beta$-glucosidase and an $N$-acetylglucosaminidase from Trichoderma harzianum. Pbytopatbology 84, 398-405.

Mauch, F., Hadwiger, L. A. \& Boller, T. (1988a). Antifungal hydrolases in pea tissue. I. Purification and characterization of two chitinases and two $\beta-1,3$-glucanases differentially regulated during development and in response to fungal infection. Plant Pbysiol $\mathbf{8 7}$, 325-333.

Mauch, F., Mauch-Mani, B. \& Boller, T. (1988b). Antifungal hydrolysis in pea tissue. II. Inhibition of fungal growth by combinations of chitinase and $\beta-1,3$-glucanase. Plant Pbysiol 88, 936-942.

Melcher, L. S., Apotheker-de Groot, M., van der Knaap, J., Ponstein, A. S., Sela-Buurlage, M., Bol, J. F., Cornelissen, B. J. C., van den Eizen, P. J. M. \& Linthorst, H. J. M. (1994). A new class of tobacco chitinases homologous to bacterial exo-chitinases displays antifungal activity. Plant J 5, 469-480.

Migheli, Q., Friard, O., Ramon-Vidal, D. \& Gonzalez-Candelas, L. (1994). Hypercellulolytic transformants of Trichoderma longibrachiatum are active in reducing Pytbium damping-off on cucumber. In Advances in Molecular Genetics of Plant-Micrabe Interactions, vol. 3, pp. 395-398. Edited by M. J. Daniels. Dordrecht, The Netherlands: Kluwer Academic Publishers.

Pitson, S. M., Seviour, R. J. \& McDougall, B. M. (1993). Noncelluloytic fungal $\beta$-glucanases: their physiology and regulation. Enzyme Microb Technol 15, 178-192.

Reese, E. T. \& Mandels, M. (1963). Enzymatic hydrolysis of $\beta$ glucans. In Advances in Enzymatic Hydrolysis of Cellulose and Related Material, pp. 197-234. Edited by E. T. Reese. Oxford: Pergamon Press.

Ridout, C. J., Colry-Smith, J. R. \& Lynch, J. M. (1988). Fractionation of extracellular enzymes from a mycoparasitic strain of T. barzianum. Enzyme Microb Technol 10, 180-187.

Sahai, A. S. \& Manocha, M. S. (1993). Chitinases of fungi and plants: their involvement in morphogenesis and host-parasite interaction. FEMS Microbiol Rev 11, 317-338. 
Sanchez-Torres, P., Gonzalez, R., Perez-Gonzalez, J. A., GonzalezCandelas L. \& Ramon, D. (1994). Development of a transformation system for Tricboderma longibrachiatum and its use to construct multicopy transformants for eg/1 gene. Appl Microbiol Biotechnol 41, 440-446.

Schippers, B., Lugtenberg, B. \& Weisbeek, P. J. (1987). Plant growth control by fluorescent pseudomonas. In Innovative Approacbes to Plant Disease Control, pp. 19-39. Edited by I. Chet. New York: J. Wiley \& Sons.

Schirmb\&ck. M., Lorito, M., Wang, Y. L., Hayes, C. K., Arsian-Atac, I., Scala, F., Harman, G. E. \& Kubicek, C. P. (1994). Parallel formation and synergism of hydrolytic enzymes and peptaibol antibiotics, molecular mechanisms involved in the antagonistic action of Trichoderma barzianum against phytopathogenic fungi. Appl Environ Microbiol 60, 4364-4370.

Schlumbaum, A., Mauch, F., Vogeli, U. \& Boller, T. (1986). Plant chitinases are potent inhibitors of fungal growth. Nature 324, 365-367.

Shapira, R., Ordentlich, A., Chet, I. \& Oppenheim, A. B. (1989). Control of plant diseases by chitinase expressed from cloned DNA in Escherichia coli. Pbytopatbology 79, 1246-1249.

Sitrit, Y., Barak, Z.، Kapulnik, Y., Oppenheim, A. \& Chet, I. (1993). Expression of Serratia marcescens chitinase gene in Rbizobium meliloti during symbiosis on alfalfa roots. Mol Plant-Microbe Interact 6, 293-298.

Sivan, A. \& Chet, I. (1989). Degradation of fungal cell walls by lytic enzymes of Trichoderma barzianum. I Gen Microbiol 135, 675-682.

Tangarone, B., Royer, J. C. \& Nakas, J. P. (1989). Purification and characterization of an endo-1,3,- $\beta$-D-glucanase from Trichoderma longibracbiatum. Appl Environ Microbiol 55, 177-184.

Ulhoa, C. J. \& Peberdy, J. F. (1991). Purification and characterization of an extracellular chitobiase from Trichoderma barzianum. Curr Microbiol 23, 285-289.

Ulhoa, C. J. \& Peberdy, J. F. (1992). Purification and some properties of the extracellular chitinase produced by Trichoderma barzianum. Enzyme Microb Technol 14, 236-241.

Vasseur, V., Van Montagu, M. \& Goldman, G. H. (1995). Trichoderma barzianum genes induced during growth on Rbizoctonia solani cell walls. Microbiology 141, 767-774.

Waard, M. A. D., Georgopoulos, S. G., Hollomon, D. W., Ishii, H., Leroux, P., Ragsdale, N. N. \& Schwinn, F. J. (1993). Chemical control of plant diseases: problems and prospects. Annu Rev Pbitopaibol 31, 403-421.

Weller, D. M. (1988). Biological control of soilborne plant pathogens in the rhizosphere with bacteria. Annu Rev Phytopatbol 26, $379-407$.

Wessels, J. G. H. \& Siestma, J. H. (1981). Fungal cell walls: a survey. In Encyclopedia of Plant Physiology, 13B, pp. 352-394. Edited by W. Tanner \& F. A Loewus. Berlin: Springer-Verlag.

Yamamoto, R. \& Nevins, D. J. (1983). Degradation of a glucan containing $\beta$-(1-3) and $\beta-(1-6)$ linkages by exo-(1-3)- $\beta$-D-glucanase. Carbobydr Res 122, 217-226.

Zevenhuizen, L. P. T. M. \& Bartnicki-Garcia, S. (1970). Structure and tole of a soluble cytoplasmic glucan from Pbytophtbora cinnamomi. J Gen Micrabiol 61, 183-188. 